\title{
BRCA1 Polymorphism Positive
}

National Cancer Institute

\section{Source}

National Cancer Institute. BRCA1 Polymorphism Positive. NCI Thesaurus. Code C146648.

An indication that polymorphism of the BRCA1 gene has been detected in a sample. 